\title{
NUCLEAR SCIENCE, EDUCATION, AND TRAINING AT THE ARGONAUTA RESEARCH REACTOR IN BRAZIL
}

\section{COMMUNICATIONS}

CARVALHEIRA, Luciana ${ }^{1}$

NUNES, Rogerio Chaffin ${ }^{2}$

FERREIRA, Francisco José de Oliveira ${ }^{3}$

CARVALHEIRA, Luciana. NUNES, Rogerio Chaffin. FERREIRA, Francisco José de Oliveira. Nuclear Science, Education, and Training at the Argonauta research reactor in Brazil. Revista Científica Multidisciplinar Núcleo do Conhecimento. Year 05, Ed. 11, Vol. 16, pp. 05-18. November 2020. ISSN:2448-0959, Access link in: https://www.nucleodoconhecimento.com.br/education/nuclear-science

\section{ABSTRACT}

This work presents the contribution of the Argonauta research reactor in the education and training of human resources in Nuclear Sciences. Since 1965, the Argonauta reactor, located at Rio de Janeiro, Brazil, has been offering theoretical and experimental classes to undergraduate and graduate students. Nuclear Physics and Reactor Physics are the major areas included in the classes provided by the Argonauta's staff. Recently, Radiochemical classes were integrated in the program. The Argonauta reactor showed to provide substantial contributions to training and formation in the nuclear domain besides improving its capacity to develop know-how in the areas of Nuclear Science.

\footnotetext{
${ }^{1}$ Researcher.

2 Technologist.

3 Technologist.
} 
Keywords: Knowledge, Nuclear Science, Argonauta reactor.

\section{INTRODUCTION}

A research reactor plays an important role in the training of human resources in the nuclear field. For example, this kind of nuclear facility allows projecting an entire new nuclear reactor and its facilities, considering also regulation and security aspects. The Argonauta research reactor, located at Rio de Janeiro, was inaugurated in 1965 (Fig. 1). This reactor is part of the Nuclear Engineering Institute (IEN) that integrates the National Commission for Nuclear Energy. On the internet is possible to find a professional video about Argonauta's construction, showing the building of the reactor, the fuel element manufacturing and the inauguration ceremony with its first criticality (Nuclear Engineering Institute, 2019; MELLO, 2019). By that time, the control desk and its electronic devices, i.e., the reactor brain used to be with the reactor in the same saloon. Later in 1989, the reactor brain was moved from its original place to an isolated and shielded room. In 2013, a technical visiting to the Argonauta by means of virtual reality was elaborated (MÓL et al., 2013).

Fig. 1 External (a) and internal (a) views of the Argonauta reactor

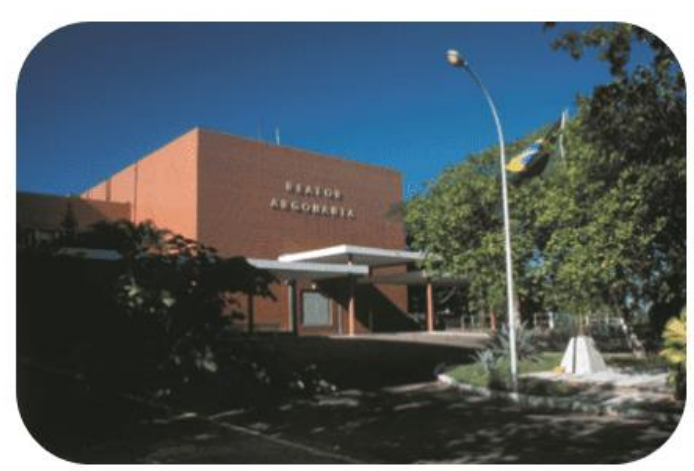

(a)

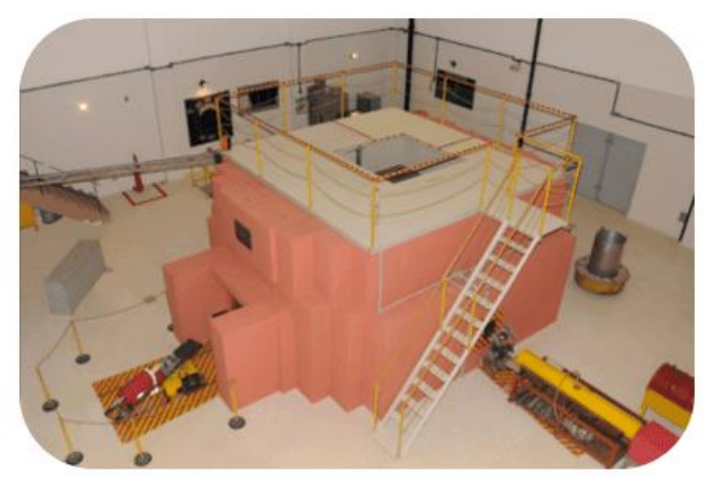

(b)

Source: Adapted from Nuclear Engineering Institute, 2019

Annually, the Argonauta reactor operates an average criticality of $350 \mathrm{~h}$ with a staff composed by 4 operators being one of them the senior. In 1994, the reactor underwent a modification at its core. Ten original defective fuel plates were removed and replaced 
with 26 new fuel plates which have approximately half the original mass of uranium 235. Fig. 2 illustrates the actual core of the Argonauta reactor that consists of two concentric aluminum cylinders. The smaller diameter cylinder is filled with graphite. This region is called as internal thermal column and has five access holes (drawers) for experimental measurements. The ring formed between the two cylinders has twenty-four positions for placement of fuel elements spaced by graphite wedges. In positions not used by these elements are placed blocks of graphite with the same dimensions. Near the reactor core, there is the $\mathrm{J} 9$ irradiation channel that is the most used (Fig. 3). This irradiation channel allows the activation of different materials and substances such as gold leaves, blood samples and polymeric particles. A long graphite block contains 3 entrance holes to hold the samples to be activated. After samples insertion, this block is moved to the inner part of the reactor until touching the external surface of its core (SILVANI; FURIERI, 2001; RENKE; FERREIRA, 2012).

Fig. 2 Illustration of the actual Argonauta reactor core (the new plates are colored in light blue and the original ones are in deep blue)

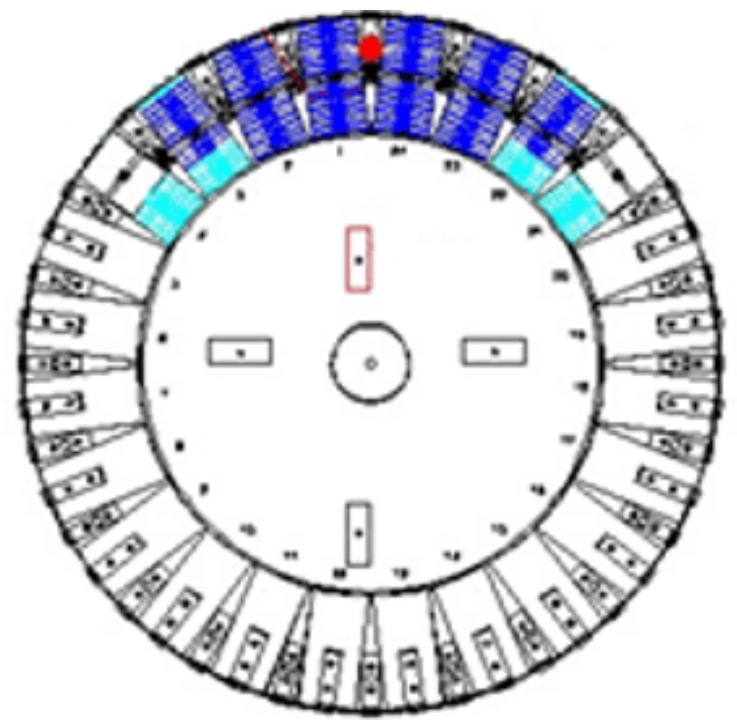

Source: Adapted from Silvani e Furieri, 2001 
Fig. 3 Illustration of the $\mathrm{J} 9$ irradiation channel (graphite as reflector and concrete as shielding are represented by diagonal lines and dark points, respectively)

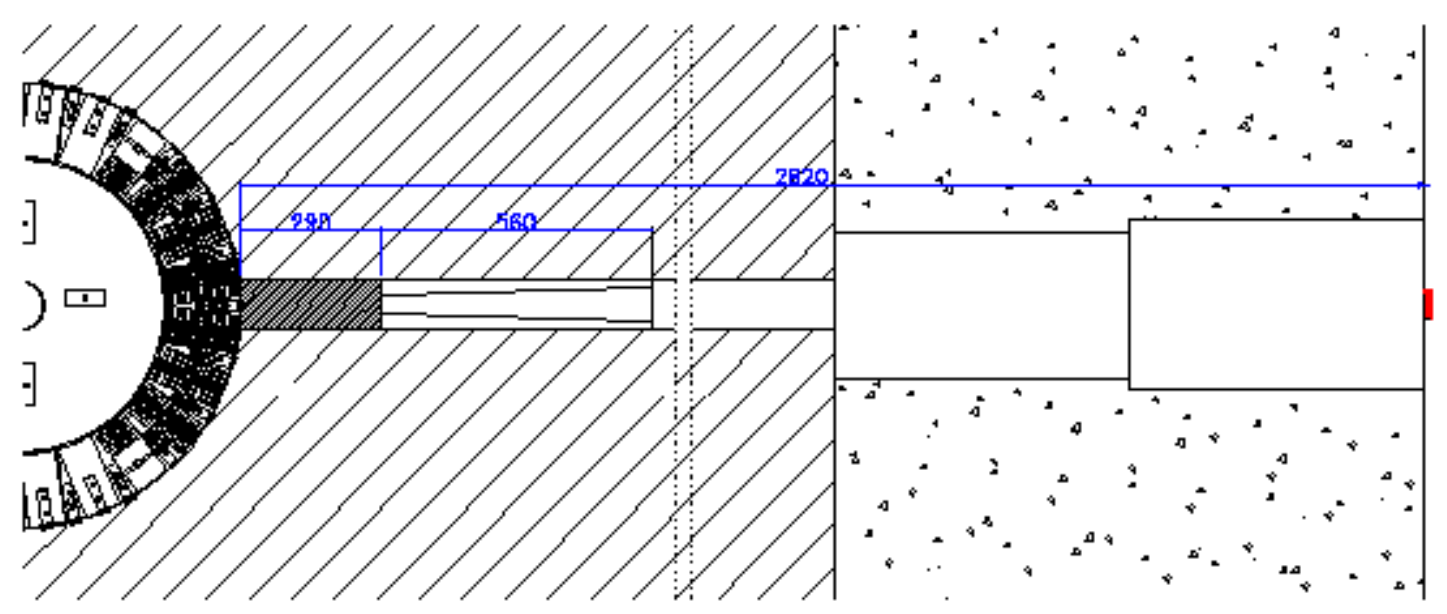

Source: Adapted from Silvani e Furieri, 2001

Also, the Argonauta reactor is an important tool for the scale up of the Brazilian Multipurpose Research Reactor (RMB). RMB has been built to provide radioisotopes for health, environment and industry applications in order to promote scientific and technological development (PERROTA; SOARES, 2015). Recently, a new laboratory was created to perform research and development in Radiochemistry by using radioisotopes obtained from neutron activation.

Efforts have been made to preserve the body of nuclear knowledge through several education programs. There is a constant need of supplying new qualified personnel to sustain all the research and technologies developed and to face upcoming challenges in the nuclear field. Accordingly, initiatives on the dissemination of the peaceful uses of the nuclear energy are of great value since they attract potential undergraduate students to the nuclear field. Indeed, practical trainings are offered to engage students in the nuclear field (MEYER; VIVIER, 2007; Lartigue; Martinez, 2008; Semmler; Catharino; Vasconcellos, 2012; International Atomic Energy Agency, 2016; LEVY; SORDI; VILLAVICENCIO, 2018). In Rio de Janeiro, the Argonauta reactor has been successfully enhancing the knowledge in Nuclear Science and Technology, as presented in the following sections. 


\subsection{NUCLEAR SCIENCE}

Neutrongraphy is a powerful imaging technique that reveals the presence of materials not sensible to X-Ray. The Argonauta reactor offers this imaging as a service for the quality control of some materials used in the aerospace industry (Ferreira; Silva; Crispim, 2010; Luiz; Crispim; Ferreira, 2010; Luiz; Crispim, 2017). The neutron activation of substances has been used to produce the radioisotopes lanthanum 140, gadolinium 158 and 156, bromide 82 and silver $110 \mathrm{~m}$, for example, to be used in Research, Development and Innovation (Ferreira; Crispim; SILVA, 2010; BRANDÃO et al., 2013]. Tomographic images acquired with thermal neutrons demonstrated to be a complementary technique to the X-ray tomography in some cases (SOUZA et al., 2003).

Neutron cross-sections measurements of amino acids have been arising as a potential analytical tool for proteins and enzymes identification. The data parceling and grouping $(P \& G)$ and the data equivalence and similarity (E\&S) methods allow the manipulation of cross-sections for small functional groups from a molecule to its entire cross-section. Over 20 human amino acids were successfully tested and measured showing that these methods can be used to evaluate the quality of enteral and parenteral administration in patients, for example (VOI et al., 2018; NUNES et al., 2018).

\subsection{EDUCATION}

In Rio de Janeiro, for more than 50 years, the Argonauta reactor has been meeting the needs of training human resources in nuclear physics and reactor physics. Nowadays, both the undergraduate courses of Nuclear Engineering and Medical Physics and the graduate courses of Nuclear Physics and Reactor Physics are assisted by the Argonauta's staff of specialists and operators. Theoretical and practical classes that last $3.5 \mathrm{~h}$ cover fundamental topics of both nuclear and reactor physics. Recently, the Radiochemistry field was added to this program. Before the exam, a guided study is provided to elucidate doubts and to prepare the students for the exam. Seminars are the exam methodology used to evaluate the students' performance. In three months, 
the students accomplish the program and receive a certificate. Table 1 displays the program offered by the Argonauta's staff.

Once a week, internal seminars are performed to keep up with the scientific works being developed and acquired knowledge by Argonauta's staff, students and collaborators. Regularly, high school students from private and public schools visit Argonauta reactor facilities as a primary contact with the peaceful and beneficial applications of nuclear energy. Power generation, Neutrongraphy and Radiological Protection are the topics presented to these students. In addition, a reactor mock-up and real scale replicas of the nucleus and the fuel element are used to illustrate these topics (Fig. 4).

Table 1 The Argonauta Reactor program for graduate and undergraduate students

\begin{tabular}{|c|c|}
\hline Topics & Number of classes \\
\hline Argonauta reactor description & \multirow{8}{*}{1} \\
\hline Argonauta reactor operation ${ }^{\star}$ & \\
\hline Fundamentals of neutron and kinetic & \\
\hline Subcritical approximation* & \\
\hline Control bar calibration* & \\
\hline Measurements of neutron flux ${ }^{*}$ & \\
\hline Temperature and empty coefficients ${ }^{*}$ & \\
\hline Slow neutron detection* & \\
\hline Cross-section measurements ${ }^{*}$ & 2 \\
\hline Radiochemistry & \multirow[b]{3}{*}{1} \\
\hline Guided study & \\
\hline Exam & \\
\hline
\end{tabular}

${ }^{*}$ Theoretical and practical casses

Source: the authors 
Fig. 4 Argonauta mock-up (a), fuel element (b) and nucleus containing the external control bar (c)

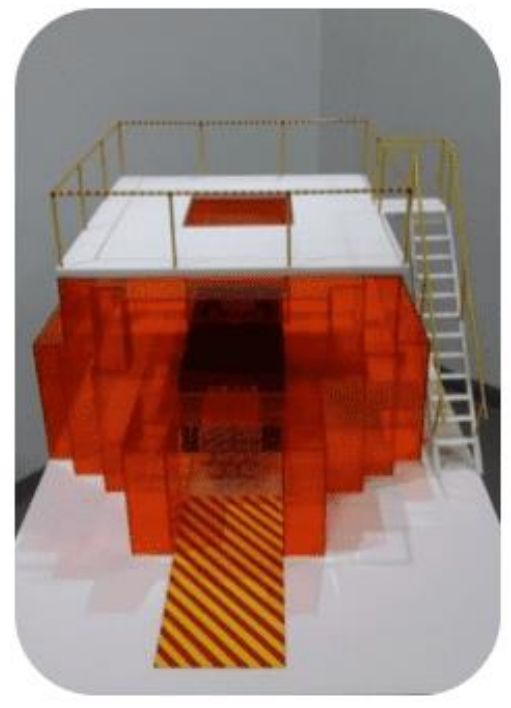

(a)

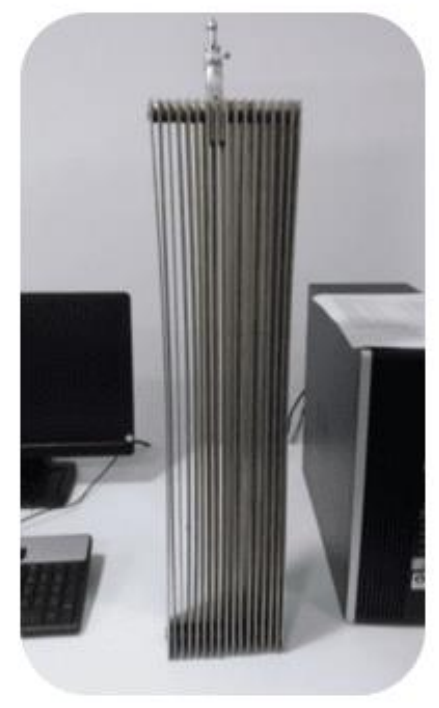

(b)

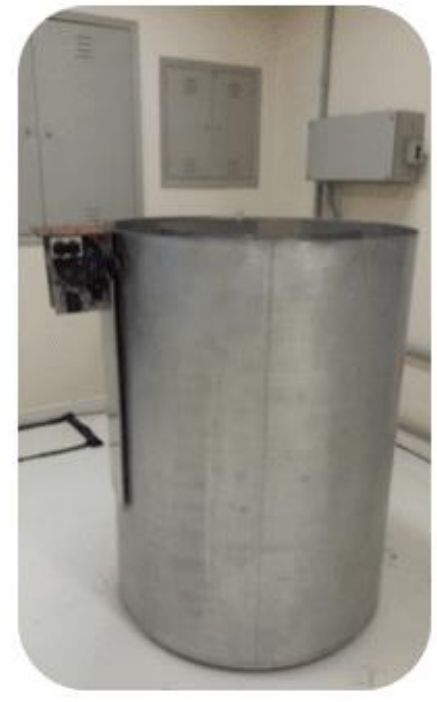

(c)

Source: the authors

Fig. 5 presents a timeline from the inauguration of the Argonauta reactor of the IEN in 1965 to the present moment. Indeed, the qualification of labor in the nuclear area is another highlight of this research reactor, which usage produced a total of 86 academic works between dissertations and theses. Valuable to note that among all IEN partner institutions, the cooperation with the Nuclear Engineering Program of the Alberto Luiz Coimbra Institute for Graduate Studies and Engineering Research of the Federal University of Rio de Janeiro (PEN/COPPE/UFRJ), inaugurated in 1968, was the most fruitful, 68 in total, 50 masters and 18 doctorates completed. 
Fig. 5 Number of academical works developed using the Argonauta reactor since its inauguration

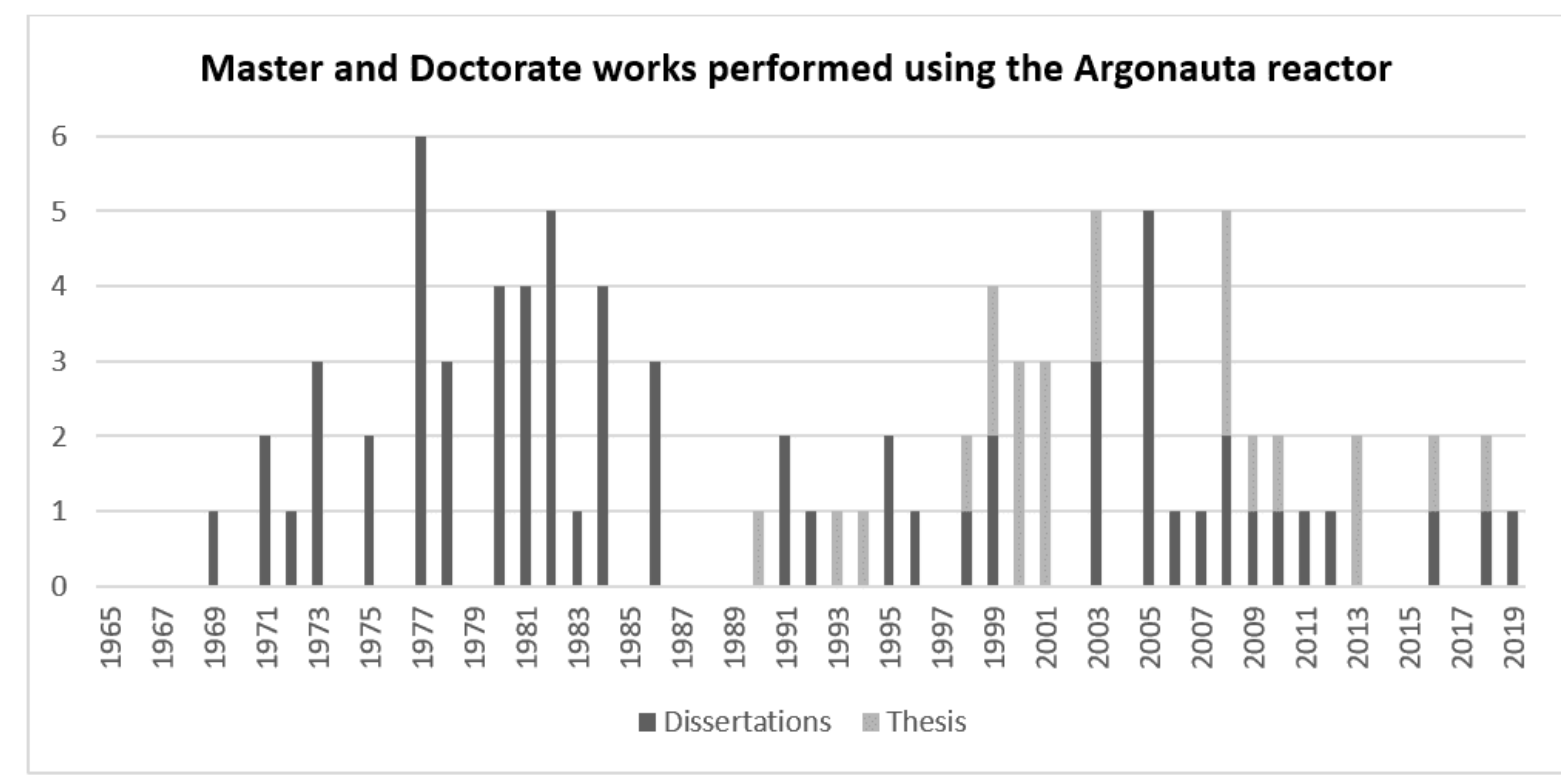

Source: the authors

The inaugural result of the collaboration with PEN/COPPE/UFRJ was the first master dissertation from the use of the Argonauta Research Reactor, named as 'Study of the Scattering of Thermal Neutrons in Water', being elaborated by the physicist Luiz Pinguelli Rosa, in 1969, under the academic guidance of Luiz Osório de Brito Aghina, a researcher of IEN. From the same institutional partnership derived the first doctoral thesis in 1990, produced by the physicist Dante Luiz Voi, with the title 'Determination of Diffusion Shock Sections Doubly Differentiated of Neutrons for the Bakelite', being oriented by José Carlos Borges, professor at PEN/COPPE/UFRJ.

In 2004, the Professional Master's Course in Reactor Engineering started at IEN and was replaced by the Academic Master's Course in Nuclear Science and Technology in 2010. To date, 3 dissertations have been completed by using the Argonauta reactor. One more is expected to finish in 2020, via a remote defense session due to the Covid19 pandemic. In the near future, this participation will increase as infrastructure improvements and the acquisition of new equipment are being carried out to improve 
the Argonauta Reactor's facilities. Such update will facilitate and stimulate the development of new studies and projects.

In 2017, a staff of Brazilian navy officers stayed at the Argonauta Reactor during two weeks to have theoretical and practical classes. Still in this year, for the first time, the Argonauta's staff received 4 students with scholarships sponsored by the National Council for Scientific and Technological Development that is one of the most important government funding for Science and Technology in Brazil. Moreover, the classes offered to undergraduate and graduate students have attended, so far, the total number of about 800 students.

\subsection{TRAINING}

Accordingly to the regulation applied to research reactors in Brazil, these nuclear facilities must provide a requalification program for licensed operators. This program follows a biannual schedule, with a duration of approximately 75 hours per year of study besides clinical exams. The Argonauta reactor offers technical updates in the reactor operation through theoretical and practical training. For the recycling of theoretical concepts, the adopted methodology consists of a guided study of a didactic material that includes regulatory issues, safety, and Nuclear Physics (Table 2), in addition to the participation of the operators in the seminars offered by graduate students. In the practical training, the operators perform the experiments carried out in the practical classes given for graduate and undergraduate students (Table 1). Moreover, during this practical training, the operator performs a complete cycle of the necessary procedures for the operation of the reactor, such as pre-operational procedures, daily reactor revision, startup, subcriticality, supercriticality, criticality adjustment for desired operating power, and the scram. In this training, to run these procedures is a distinctive feature. At the end of each annual cycle, the operators are submitted to a written evaluation test with $4 \mathrm{~h}$ of duration where 8.0 is the minimum grade for approval. New candidates from the Argonauta host institution can attend a similar program to become a licensed operator. Table 2 displays the structure of the requalification program. In 2019 , the Argonauta operators training was running at its 
correspondent second year. A new candidate for the reactor operating is expected for 2020.

Table 2 Requalification program for technical updates in the reactor operation

\begin{tabular}{|c|c|c|c|c|c|c|c|}
\hline \multicolumn{8}{|l|}{ Year $1^{*}$} \\
\hline Topics & Mar & Apr & May & \multicolumn{2}{|r|}{ Sept } & Oct & Nov \\
\hline $\begin{array}{l}\text { Description and operation of the } \\
\text { Argonauta reactor }\end{array}$ & . & . & . & & & & \\
\hline $\begin{array}{l}\text { Analyses of accidents and } \\
\text { procedures in emergency } \\
\text { situations }\end{array}$ & & & & . & . & & \\
\hline \multicolumn{2}{|l|}{ Norms and routine procedures } & & & & & . & . \\
\hline \multicolumn{8}{|l|}{ Year $2^{*}$} \\
\hline Topics & Mar & Apr & May & Jun & \multicolumn{2}{|c|}{ Sept } & Oct \\
\hline Nuclear Physics and Neutronic & - & . & & & & & \\
\hline Kinect and criticality & & & & & & & \\
\hline Radiological Protection & & & & & & & \\
\hline Experiments on the reactor & & & & & & & . \\
\hline
\end{tabular}

* The months not mentioned are dedicated to vacations and maintenance.

Source: the authors

\subsection{RD\&I AT ARGONAUTA REACTOR FACILITIES}

Some studies conducted at Argonauta have become commercial services that led to the creation of a startup company in the radiotracer field (ASSOCIAÇÃO BRASILEIRA DE ENERGIA NUCLEAR, 2019). Regarding applications in the Nutrition field, the presence of toxic metals on Brazilian beans through neutron activation has recently been studied. In addition, neutron activation analysis has been applied in the study of the presence of metals in food such as beans, fish and nuts. The objective is the quantification of toxic and oligoelements in trace level. Heavy metals present in water 
from lakes and rivers are also part of this study. Moreover, the scientific production of Argonauta's staff, about 200 papers, scientific notes, complete works and summaries on congress were produced by technologists and researchers.

\section{CONCLUSIONS}

The solid history of the Argonauta research reactor shows that this nuclear installation has always been preparing human resources for the nuclear field. In addition, the theoretical and practical activities developed within the Argonauta reactor provide substantial contributions to training and formation of workers in the nuclear domain. Therefore, the Argonauta's staff is ready and open to receive students, researchers, and collaborators that intend to experience the reactor facilities and to develop knowhow in the areas of Nuclear Science and Technology. Trainees from undergraduate courses such as Chemistry, Physics, Biology and correlated areas will soon be received at the Argonauta facilities to have their first professional experience by applying knowledge in practical situations in a real scenario. In addition, to follow the improvements concerning education and training, the program offered by the Argonauta's staff will be available online. In this way, students and professionals around the world can freely access theoretical material and be encouraged to learn and retain knowledge in the nuclear field. Besides, there are ongoing improvements regarding the development of a new subcritical assembly for the Argonauta reactor and the replacement of the fuel element by uranium silicide. By using this assembly, the whole project of a nuclear plant can be studied and developed. With this new fuel element both the range of elements to be neutron activated is broadened and the time of irradiation is reduced.

\section{REFERENCES}

ASSOCIAÇÃO BRASILEIRA DE ENERGIA NUCLEAR. Projeto Atomum torna-se empresa júnior. Availabe in: http://www.aben.com.br/noticias/ien-cnen-projeto-atmumtorna-se-empresa-junior. Accessed in 05/04/2019. 
BRANDÃO, Luis Eduardo Barreira; SALGADO, Cesar Marques; NASCIMENTO, Ana Cristina de Holanda; NUNES, Rogerio Chaffin. Wastewater plants evaluation and optimization using radioactive tracers. Progress Report, v. 1, p. 67-67, 2013.

Ferreira, José de Oliveira Ferreira; Crispim, Verginia Reis; SILVA, Ademir Xavier da. Detection of drugs and explosives using neutron computerized tomography and artificial intelligence techniques. Applied Radiation and Isotopes, v. 68, i. 6, p. 1012-1017, 2010.

Ferreira, José de Oliveira Ferreira; Silva, Ademir Xavier da, Crispim, Verginia Reis. Electronic imaging system for neutron radiography at a low power research reactor. Radiation Measurements, v. 45, i. 7, p. 806-809, 2010.

International Atomic Energy Agency. Nuclear knowledge management Challenges and Approaches. Summary of an International Conference Held in Vienna, 7-11 November 2016. Available in: https://www.iaea.org/topics/nuclear-knowledge-management. Accessed in: 04/30/2019.

Lartigue Juan, Martinez Trinidad. Radiochemistry Education in the US and abroad: Trends in Nuclear Education. Journal of Radioanalytical and Nuclear Chemistry, v. 276, p. 849-855, 2008.

Levy, Denise Sahyun, Sordi, Gian Maria Agostino Angelo, Villavicencio, Anna Lucia Casanas Haasis. Construindo pontes entre ciência e sociedade: divulgação científica sobre irradiação de alimentos. Brazilian Journal of Radiation Sciences, v. 6, i. 1, p. 113, 2018.

Luiz, Leandro da Conceição, Crispim, Verginia Reis, Ferreira, Francisco José de Oliveira. Visualization of Two-Phase Flow in Metallic Pipes Using Neutron Radiographic Technique. Physicae, v. 9, p. 19-23, 2010.

Luiz, Leandro da Conceição, Crispim, Verginia Reis. Visualization of Crust in Metallic Piping Through Real-Time Neutron Radiography Obtained with Low Intensity Thermal Neutron Flux. Nuclear Engineering and Technology, v. 49, i. 4, p. 781-786, 2017. 
MELLO, Hilton Andrade de. The Argonauta reactor construction. Avaiable in: http://www.hamello.com/sitebr/index.php/component/content/article?id=80. Accessed 07/15/2019.

Meyer, G., Vivier, A. The role of NAA in nuclear chemistry education. Journal of Radioanalytical and Nuclear Chemistry, v. 271, p. 77-82, 2007.

MÓL, Antonio Carlos de Abreu; JORGE, Carlos Alexandre Fructuoso; AGHINA, Mauricio Alves de Cunha e; PEREIRA, Cláudio Márcio do Nascimento Abreu; LANDAU, Luiz; CUNHA, Gerson Gomes da. Virtual reality and artificial intelligence for nuclear plants' environment simulation towards safety for personnel. Progress Report, v. 1, p. 119-119, 2013.

Nuclear Engineering Institute. The Argonauta reactor. Avaiable in: http://www.ien.gov.br/index.php/principais-instalacoes/57-pagina-interna/159argonauta. Accessed 05/18/2019.

NUNES, Rogerio Chaffin; Oliveira, Francisco Jose Ferreira; Salgado, César; Barbosa, A; CARVALHEIRA, Luciana; VOI, Dante Luiz. Applications of the neutron activation analysis technique in the Argonauta research reactor of the IEN. Progress Report, v. 3, p. 12-12, 2018.

Perrotta, Jose Augusto \& Soares, Adalberto Jose. RMB The new Brazilian multipurpose research reactor. Atw Internationale Zeitschrift fuer Kernenergie, v. 60, i. 1, p. 30-34, 2015.

RENKE, Carlos Alberto Curi; FERREIRA, Francisco José de Oliveira. Operation of the Argonauta Reactor. pdf. Progress Report, v. 1, p. 53-53, 2013.

Semmler, Renato, Catharino, Marília Gabriela Miranda \& Vasconcellos, Marina Beatriz Agostini. Education in nuclear science at IPEN - CNEN, São Paulo, Brazil: Advanced School of Nuclear Energy - EAEN. Journal of Radioanalytical and Nuclear Chemistry, v. 291 , p. $55-58,2012$. 
SILVANI, Maria Inês; FURIERI, Rosanne Cefaly de Aranda Amado. Mapeamento do Fluxo de Nêutrons do Reator Argonauta na Nova Configuração de seu Núcleo, RT-IEN-11, p. 42-42, 2001.

SOUZA, Maria Inês Silvani; LOPES, Ricardo Tadeu; JESUS, Edgar Oliveira de; ALMEIDA, Gevaldo Lisboa; BARBOSA, Ademarlaudo França ; FURIERI, Rosanne . Comparison of tomographic systems for X-ray and thermal neutron. Brazilian Journal of Physics, v. 33, i. 2, p. 286-290, 2003.

VOI, Dante Luiz ; ROCHA, Helio F.; Oliveira, Francisco Jose Ferreira; Nunes, Rogerio Chaffin; CARVALHEIRA, Luciana; COLLACA, Isabel Tavares. Analysis of amino acids and the construction of a neutron database using neutron spectrometry in the Argonauta reactor. Progress Report, v. 3, p. 10-10, 2018.

\section{APPENDIX - FIGURES AND TABLES IN PORTUGUESE}

Tabela 1 Programa do reator Argonauta para estudantes de graduação e de pós-graduação

\begin{tabular}{|l|l|}
\hline Tópicos & Número de aulas \\
\hline Descrição do reator Argonauta & \\
\hline Operação do reator Argonauta* & \\
\hline Fundamentos de neutrônica e cinética & \\
\hline Aproximação subcrítica & \\
\hline Calibração da barra de controle* & 1 \\
\hline Medidas de fluxo de nêutrons & \\
\hline Coeficientes de temperatura e de vazio* & \\
\hline Detecção de nêutrons lentos & \\
\hline Medidas de seção de choque* & \\
\hline Radioquímica & 2 \\
\hline Estudo dirigido & \\
\hline
\end{tabular}




\section{Avaliação}

*Aulas teóricas e práticas

Fonte: os autores

Figura 5 Número de trabalhos acadêmicos desenvolvidos com a utilização do reator Argonauta desde sua inauguração

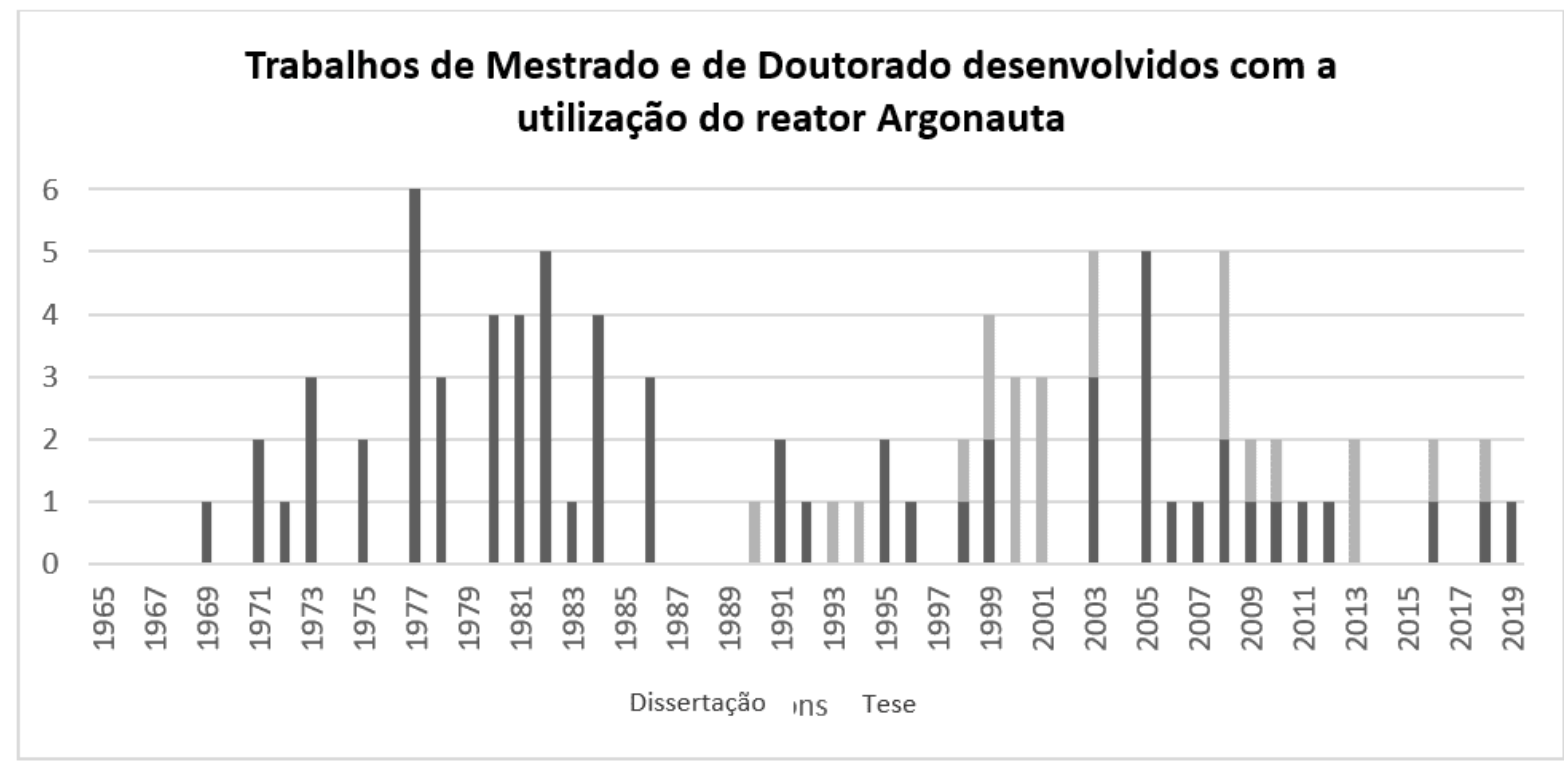

Fonte: os autores

Tabela 2 Programa de requalificação para atualizações técnicas sobre a operação do reator

\begin{tabular}{|c|c|c|c|c|c|c|c|}
\hline \multicolumn{8}{|l|}{ Ano $1^{*}$} \\
\hline Tópicos & Mar & Abr & Mai & Jul & Set & Out & Nov \\
\hline $\begin{array}{l}\text { Descrição e operação do reator } \\
\text { Argonauta }\end{array}$ & . & & & & & & \\
\hline $\begin{array}{l}\text { Análise de acidentes e } \\
\text { procedimentos em situações de } \\
\text { emergência }\end{array}$ & & & & & . & & \\
\hline Normas e procedimentos de rotina & & & & & & . & . \\
\hline
\end{tabular}




\begin{tabular}{|l|l|l|l|l|l|l|}
\hline Ano $2^{\star}$ & Mar & Abr & Mai & Jun & Set & Out \\
\hline Tópicos & $\cdot$ & $\cdot$ & & & & \\
\hline Física Nuclear e Neutrônica & & & $\cdot$ & $\cdot$ & & \\
\hline Cinética e criticalidade & & & & & $\cdot$ & \\
\hline Proteção Radiológica & & & & & & . \\
\hline Experimentos no reator & & & \\
\hline
\end{tabular}

* Os meses não mencionados são dedicados às férias e manutenção

Fonte: os autores

Submitted: July, 2020.

Approved: November, 2020. 